\title{
IMPLEMENTASI POLITIK HUKUM ISLAM DALAM PERUMUSAN PIAGAM JAKARTA
}

\author{
Sasmiarti \\ LAIN Bukittinggi, sasmiarti@gmail.com \\ Edi Rosman \\ LAIN Bukittinggi,edi.rosman@gmail.com
}

Diterima: 10 Januari 2018

Direvisi : 14 Maret 2018

Diterbitkan: 30 Juni 2018

\begin{abstract}
Indonesia is a plural and multicultural country. But in the diversity embedded sense of diversity. The taste was clearly visible during the preparation of Indonesian independence. People of various nationalities, nations and religions join hands to prepare for Indonesian independence, from the basic formulation of the state, basic law and other texts that are important for an independent Indonesia. Seeing the development that occurred at that time the nation's leaders are only clarified into two major groups namely Islamic groups and Nationalist groups. This study aims to reveal the efforts and influence of Islamic groups and Islamic societies in the political development of Islamic law in Indonesia, especially in the formulation of the Indonesian Basic State independence, especially the Jakarta Charter. To answer that question is a historical research approach, with a history of preparation for Indonesian independence. By examining the existing literature, it was found that at first the basic formulation of the State contained in the Jakarta Charter reflected the political influence of Islamic law. But then there is a change based on the consensus of national figures on the grounds of the integrity of the nation and the State. The results of this study are expected to provide valuable contribution to realize the ideals of Indonesian Islamic society, so that the politics of Islamic law really color the life of nation and state even though Indonesia is not an Islamic State.
\end{abstract}

Keywords: Phylosophy of Nation, Jakarta Charter, Islamic Law Politics

\begin{abstract}
Abstrak
Indonesia adalah Negara yang plural dan multikultural. Akan tetapi dalam keberagaman tersebut tertanam rasa kebhinnekaan. Rasa itu benar-benar terlihat jelas pada waktu persiapan kemerdekaan Indonesia. Tokoh bangsa dari berbagai suku, bangsa dan agama saling bergandeng tangan untuk mempersiapkan kemerdekaan Indonesia, mulai dari perumusan dasar negara, bukum dasar dan naskah lainnya yang penting bagi Indonesia merdeka. Melihat perkembangan yang terjadi pada waktu itu para tokoh bangsa tersebut hanya terklasfikasi ke dalam 2 kelompok besar yaitu kelompok Islam dan kelompok. Nasionalis. Penelitian ini bertujuan untuk mengungkap usaha dan pengarub kelompok Islam dan masyarakat Islam dalam perkembangan politik bukum Islam di Indonesia terutama dalam perumusan Dasar Negara Indonesia merdeka khusunya Piagam Jakarta. Untuk menjawab pertanyaan tersebut dilakukan pendekatan penelitian historis, dengan mengakaji sejarah persiapan kemerdekaan Indonesia. Dengan meneliti literature yang ada, ditemukan jawaban bahwa pada awalnya rumusan dasar Negara yang termuat di dalam Piagam Jakarta telah mencerminkan adanya pengarub politik bukum Islam. Akan tetapi kemudian terjadi perubahan berdasarkan konsensus tokoh-tokoh bangsa dengan alasan keutuhan bangsa dan Negara. Hasil kajian ini diharapkan mampu memberikan kontribusi berharga untuk meijudkan cita-cita masyarakat Islam Indonesia, sehingga politik bukum Islam benar-benar mewarnai kehidupan berbangsa dan bernegara sekalipun Indonesia bukan Negara Islam.
\end{abstract}

Kata Kunci: Dasar Negara, Piagam Jakarta, Politik Hukum Islam

\section{PENDAHULUAN}

Sejak dahulu mulai zaman pra penjajahan sampai sekarang ini masyarakat Indonesia merupakan masyarakat dengan tingkat keanekaragaman yang sangat kompleks. Masyarakat Indonesia sangat beragam dalam adat-istiadat, ras, bahasa dan agama. Masyarakat dengan berbagai keanekaragaman 
tersebut dikenal saat ini dengan istilah mayarakat multikultural, atau pada zaman dahulu disebut dengan masyarakat yang Bhinneka. Dengan kemajemukan inilah Mpu Tantular di dalam kitabnya yang bernama Sutasoma mencantumkan semboyan Bhinneka Tunggal Ika. Bhinneka Tunggal Ika bermakna walaupun berbeda-beda tetapi tetap satu.

Kemajemukan masyarakat Indonesia dapat diartikan sebagai keragaman atau perbedaan dalam agama yang dianut. Kadangkala agama yang dianut melekat pada latar belakang daerah yang ditempati oleh suatu masyarakat. Sebagai contoh masyarakat yang tinggal di Aceh dan Minangkabau akan terkenal dengan Agama Islamnya, sedangkan masyarakat yang tinggal di Sumatera Utara atau di Ambon akan lebih terkenal dengan Agama Nasraninya. Walaupun antar suku bangsa memiliki ciri khas agama dan budaya yang berbeda akan tetapi mereka memiliki rasa kesatuan sebagai bagian dari bangsa Indonesia.

Berkaitan dengan hal ini, Soekarno pernah menegaskan, saat ditanya mengenai siapa bangsa Indonesia. Beliau mengatakan bahwa bangsa Indonesia adalah semua suku yang mendiami wilayah bekas jajahan Hindia Belanda, baik keturunan maupun siapa pun yang memiliki kesamaan watak, hasrat kuat bersatu padu dan rasa senasib sepenanggungan akibat penjajahan. Jadi jika bertitik tolak pada pernyataan Soekarno tersebut maka jelaslah bahwa bangsa Indonesia terbentuk bukan karena kesamaan warna kulit, gologan, ras ataupun agama melainkan karena rasa kesatuan yang kuat atas dasar kedamaian dan kemerdekaan sejati.

Rasa persatuan ini terlihat sekali pada waktu mempersiapkan kemerdekaan Indonesia. Persiapan kemerdekaan Indonesia dilakukan oleh tokoh-tokoh bangsa yang mempunyai latar belakang budaya dan agama berbeda. Dengan semangat persatuan dan kekompakan tanpa memandang kepentingan pribadi dan agama, para tokoh tersebut berhasil memproklamirkan kemerdekaan Indonesia dan merumuskan dasar negara dalam suasana yang penuh keterbatasan.

Perumusan dasar negara Indonesia, memakan waktu yang cukup panjang, karena mengingat dasar negara adalah fondasi yang akan dijadikan pedoman dalam kehidupan berbangsa dan bernegara yang meliputi seperti apa cita-cita negara, untuk apa negara ini dan bagaimana norma-norma dalam bernegara. Ia harus mencerminkan nilai-nilai yang digali dari kehidupan bangsa dan harus dapat memanifestasikan nilai-nilai tersebut di dalam ketatanegaraan Indonesia. Negara yang tidak memiliki dasar negara maka negara tersebut tidak memiliki sebuah pedoman dalam menjalankan kehidupan bernegara sehingga berakibat ketidakjelasan arah dan tujuan yang dimiliki oleh negara tersebut dan akan menimbulkan kekacauan dengan mudah. Oleh karena itu, sangat dibutuhkan dasar negara agar dapat menjadi sebuah pedoman hidup dalam menjalankan negara.

Perumusan dasar negara Republik Indonesia mulai disusun pasca pembentukan BPUPKI. Pada sidang pertama BPUPKI tanggal 29 Mei-1 Juni 1945 membahas mengenai pembentukan dasar negara. Pada sidang pertama ini ada tiga tokoh yang mengemukakan dasar negara yaitu Moh Yamin, Supomo dan pada hari terakhir adalah Soekarno. Pasca sidang BPUPKI yang pertama kemudian dilanjutkan dengan pembentukan panitia kecil yang disebut dengan Panitia Sembilan. Hasil dari panitia Sembilan yang dikenal dengan Piagam Jakarta kemudian disahkan oleh PPKI pada sidang pertama tanggal 18 Agustus 1945 dengan beberapa perubahan.

Dari latar belakang yang diuraikan di atas timbul pertanyaan; Kenapa sampai terjadi perubahan rumusan dasar negara yang terdapat pada Piagam Jakarta, Apa tujuan perubahan tersebut, Bagaimana suasana politik hukum Islam pada masa seputar kemerdekaan? 
Artikel ini bertujuan menjawab pertanyaan-pertanyaan di atas secara deskriptif dan anlitis berbasis historis.

\section{POLITIK HUKUM ISLAM}

Hukum Islam dan politik adalah dua sisi yang tidak bisa dipisahkan dalam suatu masyarakat Islam. Hukum Islam tanpa dukungan politik sulit digali dan diterapkan. Politik yang mengabaikan hukum Islam akan mengakibatkan kekacauan dalam masyarakat. Semakin baik hubungan Islam dan politik semakin besar peluang hukum Islam diaktualisasikan, dan semakin renggang hubungan Islam dan politik, semakin kecil peluang hukum Islam diterapkan

Dalam Islam istilah politik hukum disebut dengan as-Siyasah as-Syar'iyyah yang merupakan aplikasi dari al-maslahah almursalah, yaitu mengatur kesejahteraan manusia dengan hukum yang ketentuan-ketentuannya tidak termuat dalam syara'. Sebagian ulama mendefinisikan politik hukum Islam sebagai perluasan peran penguasa untuk merealisasikan kemaslahatan manusia sepanjang hal-hal tersebut tidak bertentangan dengan Islam. Secara definitif para ulama telah mengemukakan makna dari Siyasah Syar'iyah seperti berikut.

Abdul Wahab khalaf, menjelaskan bahwa siayasah syar'iyah adalah pengaturan urusan pemerintahankaum muslimin secara menyeluruh dengan cara mewujudkan maslahat, mencegah terjadinya kerusakan (mafsadat) melalui bataan-batasan yang dtetapkan oleh syara dan prinsip-prinsip umum syariat (maqasidus syariab)-kendati hal tadi tidak ada dalam ketetapan nash dan hanya menyandarkan pendapat para imam mujtahid"1. Dalam siyasah syariyah, pihak penguasa berhak untuk mengatur segala

1 Abdul Wahab Khallaf, Siyasah Syar iyyah $A w$ Nizam al-Daulah Islamiyah Fi Syun al-Dusturiyah wa alKharijiah wa al-Maliyab; Kaherah, Dar al-Ansar, 1982, h. 15 persoalan Negara Islam sejalan dengan prinsip pokok dasar-dasar agama. $^{2}$

Definisi ini lebih dipertegas oleh Abdurrahman taj yang merumuskan siyasah syariyah sebagai hukum-hukum yang mengatur kepentingan Negara, mengorganisasi permasalahan umat sesuai dengan jiwa (semangat) syariat dan dasar-dasarnya yang universal demi terciptanya tujuan-tujuan kemasyarakatan, walaupun pengaturan tersebut tidak ditegaskan baik oleh Alquran maupun alsunah. ${ }^{3}$

Ismail Sunny, mengilustrasikan politik hukum sebagai suatu proses penerimaan hukum Islam digambarkan kedudukannya menjadi dua periode yakni pertama, periode persuasive source di mana setiap orang Islam diyakini mau menerima keberlakuan hukum Islam itu; dan kedua, periode authority source di mana setiap orang Islam menyakini bahwa hukum Islam memiliki kekuatan yang harus dilaksanakan. Dengan kata lain, hukum Islam dapat berlaku secara yuridis formal apabila dikodifikasikan dalam perundang-undangan nasional. ${ }^{4}$

Dengan menganalisis definisi-definisi yang di kemukakan para ahli di atas dapat dipahami bahwa hakikat siyasah syar'iyah, berhubungan dengan pengurusan dan pengaturan kehidupan manusia, yang dilakukan oleh pemegang kekuasaan (ulul amri), yang bertujuan untuk menciptakan kemaslahatan dan menolak kemudharatan, serta pengaturan tersebut tidak boleh bertentangan dengan syariat islam. Berdasarkan hakikat siyasah syar'iyah ini dapat disimpulkan bahwa sumber-sumber pokok siyasah syar'iyah adalah Alquran dan Sunnah.

\footnotetext{
${ }^{2}$ Moh. Mahfud, MD., Politik Hukum di Indonesia, Jakarta : LP3ES, 1998, h. 9.

3 Abdurrahman Taj, Al-siyasab al-Syariyah wa alFigh al-Islami, Mesir : Mathba'ah Dar al-Ta'lif, 1993, h. 10.

${ }^{4}$ Isma'il Sunny, Tradisi dan Inovasi Keislaman di IndonesIa dalam Bidang Hukum Islam, dikutip dari Bunga Rampai Peradilan Islam di Indonesia, Jilid I, (Bandung: Ulul Albab Press, 1997), h. 40-43.
} 
Sumber inilah yang menjadi acuan bagi pemegang pemerintahan untuk menciptakan peraturan perundang-undangan dan mengatur kehidupan bernegara.

Para ulama berbeda pendapat dalam menentukan ruang lingkup kajian fiqh siyasah, diantaranya ada yang menetapkan lima bidang. Namun ada pula yang menetapkan kepada empat atau tiga bidang pembahasan. Bahkan ada sebagian ulama yang membagi ruang lingkup kajian fiqh siyasah menjadi delapan bidang.

Berdasarkan perbedaan pendapat di atas, pembagian fiqh siyasah dapat disederhanakan menjadi tiga bagian pokok. Pertama politik perundang-undangan (al-siyasah al-dusturiyah). Bagian ini meliputi pengkajian tentang penetapan hukum (tasyriiyah) oleh lembaga legislatif, peradilan (qadha'iyah) oleh lembaga yudikatif, dan administrasi pemerintahan (idariyab) oleh birokrasi atau eksekutif. Kedua, politik luar negeri (al-siyasah al-kharijiah). Bagian ini mencakup hubungan keperdataan antara warga muslim dengan warga negara non-muslim (al-siyasab al-duali al'am) atau disebut juga dengan hubungan internasional. Ketiga, politik keuangan dan moneter (al-siyasah al-maliyah). Permasalahan yang termasuk dalam siyasah maliyah ini adalah negara, perdagangan internasional, kepentingan/hak-hak publik, pajak dan perbankan.

Sehubungan dengan itu, dalam rangka meujudkan konsep siyasah syar'iyah di atas dalam kehidupan bernegara, maka negara punya beberapa tugas pokok. Syaikhul Islam Ibnu Thaimiyyah mengatakan tugas utama negara ada dua, Pertama, menegakkan syariat, dan kedua, menciptakan sarana untuk menggapai tujuan tersebut. Negara harus menjadi perpanjangan tangan Allah Swt untuk melaksanakan perintah dan menjauhi larangannya dimuka bumi.

Perujudan tugas pokok tersebut dapat tercapai, jika negara memiliki prinsip yang kuat. Menurut Thahir Azhary, prinsip-prinsip nomokrasi Islam tersebut adalah kekuasaan sebagai amanah, musyawarah, keadilan, perlindungan terhadap HAM , Peradilan yang bebas, perdamaian, kesejahteraan dan ketaatan rakyat kepada pemerintah. ${ }^{5}$ Sementara Munawir Sjadzali hanya menyebutkan enam prinsip saja yang terdapat dalam Alquran, yaitu prinsip kedudukan manusia di bumi, musyawarah, ketaatan pada pemimpin, keadilan, persamaan dan hubungan baik antar umat beragama. ${ }^{6}$ Suyuti Pulungan, menyebutkan dasar dari Alquran yang dijadikan prinsip-prinsip umum pembuatan dan pelaksanaan kebijakan seorang pemimpin dalam mewujudkan kemaslahatan warga Negara dalam Siyasah, diantaranya sebagai berikut; Kedaulatan tertinggi di Tangan Allah, Prinsip Keadilan, Prinsip Persamaan (Musâwab), Prinsip Musyawarah. ${ }^{7}$

\section{DASAR NEGARA}

Dasar negara berasal dari bahasa Belanda yaitu Philosophische Grondslag yang memiliki arti norma (lag), dasar (grands) dan filsafat (philosophische). Menurut bahasa jerman yaitu Weltanschaunng yang bermakna sebagai pandangan mendasar (anshcauung) dan dunia (welt). Menurut bahasa Indonesia dasar negara terdiri dari 2 kata yaitu dasar serta negara. Dasar sendiri bermakna fundamental atau landasan, sedangkan negara adalah sebuah organisasi pada kekuasaan. Di dalamnya wajib ada rakyat, pemerintahan yang senantiasa berdaulat serta ada unsur wilayah.

Sejumlah ahli mengemukakan teori tentang dasar negara sebagai berikut: ${ }^{8}$

${ }^{5}$ Muhammad Tahir Azhary, Negara Hukum Suatu Studi Tentang Prinsip-prinsipnya dilihat dari Segi Hukum Islam, Implementasinya pada Periode Negara Madinab dan Masa Kini, Jakarta: Bulan Bintang, 1992, h. 63.

${ }^{6}$ Muhammad Iqbal, Fiqh Siyasah, Kontekstualisasi Doktrin Politik Islam, Jakarta: Penerbit Gaya Media Pratama, 2001, h. 204.

${ }^{7}$ Suyuthy Pulungan, Fiqh Siyasah, Ajaran, Sejarah dan Pemikiran, Jakarta : Rajawali, 1994, h. 6.

${ }^{8}$ Muhammad Tahir Azhary. op. cit, h. 68 
J. Rousseau berpendapat bahwa istilah dasar negara didefinisikan sebagai sebuah alat dimana mempunyai fungsi untuk menjaga adanya kemerdekaan meliputi masing-masing individu serta ketertiban hidup dari rakyat negaranya.

Aristoteles mengemukakan bahwa sebuah negara adalah perpaduan antar keluarga hingga ke sejumlah desa. Sehingga, pada titik terakhir, keduanya bisa berdiri secara mandiri yang memiliki tujuan sama. Kesamaan tujuan tersebut adalah kehormatan dan kesenangan kedua unsur tadi.

Magnus Suseno memberikan pengertian dasar negara sebagai sebuah kesatuan pada masyarakat politik. Kemudian, memiliki beberapa fungsi, yaitu menjamin, menerapkan, dan membuat norma kelakuan menjadi berlaku bagi seluruh lapisan masyarakat.

Taqiuddin an-Nabhani menjelaskan bahwa dasar negara Khalifah adalah Aqidah Islam, yang berupa iman kepada Allah, para malaikat-Nya, kitab-kitab-Nya, rasul-rasul-Nya, Hari Akhir, dan Qadha serta Qadar baik buruknya dari Allah SWT.' Aqidah Islam ini berpangkal pada dua kalimah syahadat, yaitu kesaksian Laa ilaaba illallab Mubammad rasulullah. Maka dari itu, jika dikatakan Aqidah Islam adalah dasar negara Khilafah, artinya segala pengaturan kehidupan bernegara dan bermasyarakat tidak boleh lepas dari Alquran dan Sunnah. Tidak boleh ada satu pun konsep (mafabim), kriteria (maqayis), ataupun keyakinan (qanaat) yang tidak bersumber dari Alquran dan Sunnah. ${ }^{10}$

Dari definisi yang dikemukakan di atas dapat diberikan kesimpulan bahwa dasar negara adalah cita-cita Negara yang dijadikan suatu pedoman dalam mengontrol kehidupan penyelenggaraan negara yang meliputi berbagai sektor kehidupan, dasar Negara merupakan

9 Taqiyuddin An-Nabhani, Muqaddimah alDustur, Juz I , Beirut : Darul Ummah, 2003, h.29

${ }^{10}$ Ibid, h.6. landasan kehidupan dan pegangan dalam kehidupan bernegara, dasar Negara merupakan sumber dari segala sumber hukum.

Dasar Negara merupakan landasan kehidupan suatu negara karena setiap negara pasti memiliki landasan negara dalam melaksanakan dan menjalankan kehidupan suatu negara dimana dasar negara berperan dalam mengatur penyelenggaraan suatu negara. Negara yang tidak memiliki dasar negara adalah suatu negara yang dalam penyelenggaraan kehidupan bernegara tidak memiliki pedoman, yang berarti bahwa negara tersebut tidak memiliki arah dan tujuan yang jelas, mau dibawa kemana negara ini karena dasar negara mencakup tujuan negara, cita-cita negara, dan norma negara. Negara Indonesia sendiri memiliki dasar negara yaitu pancasila. Pancasila sebagai dasar negara adalah ideologi negara Indonesia yang menjadi pandangan dan metode seluruh bangsa indonesia dalam mencapai cita-cita. Cita-cita negara Indonesia adalah masyarakat yang adil dan makmur.

Dasar Negara adalah pegangan suatu negara yang menjadi sumber dari semua sumber hukum dan tata tertib hukum yang berlaku dalam negara tersebut. Pada hakikatnya Dasar Negara disebut sebagai filsafat negara, untuk lebih mengenal tentang dasar negara, kita harus mengetahui terlebih dahulu pengertian dari filsafat itu sendiri, kata filsafat berasal dari kata "philsof" yang berarti sahabat, cinta, dan kata "sophia" yang berarti kebijaksanaan, kebenaran, belajar. Jadi Dasar Negara sebagai suatu filsafat negara adalah suatu wujud dari hasil pemikiran, kebiksanaan, maupun pembelajaran yang dibuat dalam bentuk suatu sistem dan peraturan untuk mengatur masyarakat dalam kehidupan berbangsa dan bernegara.

Dasar Negara merupakan salah satu hal yang sangat penting setelah berdirinya suatu negara. Karena apabila Negara tidak mempunyai dasar maka negara tidak memiliki pedoman yang jelas dalam menjalani 
kehidupan berbangsa dan bernegara. Sehingga tujuan yang ingin dicapai juga menjadi tidak jelas, sehingga mudah terjadi kekacauan. Oleh karena itu dasar negara mempunyai peran vital di dalam kehidupan bernegara. Pada umumnya, dasar negara dipergunakan oleh bangsa atau negara yang fungsinya adalah sebagai berikut;

Dasar berdiri dan tegaknya negara: Pemikiran yang mendalam tentang dasar negara lazim muncul ketika suatu bangsa hendak mendirikan sebuah negara. Sehingga, dasar negara berfungsi sebagai dasar berdirinya suatu negara. Sesudah negara berdiri, dasar negara dapat menjadi landasan bagi pengelolaan negara yang bersangkutan

Dasar kegiatan penyelenggaraan negara: Negara didirikan untuk mewujudkan cita-cita dan tujuan nasional suatu bangsa di bawah pimpinan para penyelenggara negara. Agar para penyelenggara negara benar-benar dapat mewujudkan tujuan nasional, mereka harus mendasarkan semua kegiatan pemerintahan pada dasar negara

Dasar partisipasi warga negara: Semua warga negara mempunyai hak dan kewajiban yang sama untuk mempertahankan negara dan partisipasi dalam upaya bersama mencapai tujuan bangsa. Dalam menggunakan hak dan menunaikan kewajibannya itu, seluruh warga negara harus berpedoman kepada dasar negara.

Dasar Pergaulan antara warga negara: Dasar negara tidak hanya menjadi dasar perhubungan antar warga negara dan negara, melainkan dengan juga dasar bagi hubungan antarwarga negara.

Dasar dan sumber bukum nasional: Seluruh aktivitas penyelenggaraan negara dan warga negara dalam kehidupan bermasyarakat, berbangsa dan bernegara harus didasarkan pada hukum yang berlaku. Dengan demikian, semua peraturan perundang-undangan yang dibentuk untuk penyelenggaraan negara harus didasarkan pada dasar negara.
Secara umum, dasar negara dari Republik Indonesia adalah Pancasila. Pernyataan ini seperti telah tertuang di dalam pembukaan Undang-Undang Dasar 1945.

\section{PERSIAPAN KEMERDEKAAN INDONESIA}

Berbicara tentang Indonesia tidak lepas dari konstelasi global Internasional, bahkan bisa dikatakan sejarah Indonesia merupakan pertarungan kepentingan sosial, politik, ekonomi. Pada tahun 1596 merupakan babak awal tertanamnya pengaruh barat di bumi Indonesia. Berdirinya VOC pada tahun 1602 merupakan jatuhnya Nusantara pada Belanda secara ekonomis dan politis. Lambat laun kehadiran VOC di Indonesia tidak hanya merupakan perkongsian dagang, tetapi berubah haluan menjadi imperium serta melakukan invansi terhadap seluruh aspek kehidupan. Hal tersebut sesuai dengan misi kedatangan bangsa Eropa ke Indonesia untuk melakukan imperialisme dan kolonialisme dengan semboyan; gold, glory dan gospel. ${ }^{11}$

Gold memiliki arti emas, yang secara filsafat merupakan kekayaan. Dengan adanya semboyan ini bangsa barat bertujuan untuk mencari kekayaan dengan melakukan ekspedisi dan penjelajahan. Bangsa barat pergi ke timur untuk mencari rempah-rempah, karena rempah-rempah di daerah Barat sangat mahal, jadi mereka mencari ke Asia untuk mendapatkan keuntungan yang melimpah dengan mencari rempah-rempah itu. Jadi bangsa barat menganggap rempah - rempah sebagai gold (emas), karena dengan menjual rempah-rempah mereka bisa menjadi kaya.

Glory dalam Bahasa Indonesia memiliki arti kejayaan. Semboyan ini merupakan motivasi bangsa barat melakukan penjelajahan samudra. Dengan tujuan mencari

${ }^{11}$ http:/ / ditakharismasafitri.blogspot.com/201 7/04/kedatangan-bangsa-eropa-dan-awal-mula.html, akses terakhir hari Senin tanggal 28 Mei 2018, pukul 14.05 WIB. 
kejayaan, bangsa barat berharap mampu menguasai dunia luar. Mereka yakin dengan menguasai dunia dapat mengantarkan mereka dalam kejayaan, baik kejayaan ekonomi, sosial, maupun yang lainnya. Sedangkan Gospel adalah keinginan bangsa barat untuk menyebarluaskan atau mengajarkan agama Nasrani ke dunia luar. Dengan semboyan keagamaan ini biasanya membuat seseorang merasa tujuan dari semuanya merupakan kebenaran Tuhan. Di Indonesia, mereka memaksa penduduk untuk berpindah agama sambil menjajah. Ajaran yang dibawa bangsa barat itu mampu berkembang pesat di penjuru tanah air.

Bangsa Eropa menjalankan misinya di Indonesia selama berabad-abad, lambat laun kekuasaan tersebut mulai rapuh dengan kemenangan Jepang pada perang Dunia II. Kemenangan Jepang atas Belanda dan sekutunya mengakibatkan Indonesia berpindah tangan ke bangsa Jepang. Pada tanggal 10 Januari 1942 terjadi penyerbuan Jepang ke Indonesia dan tanggal 8 Maret 1942 pihak Belanda di Jawa menyerah. Jepang menjajah Indoensia dalam kurun waktu 3,5 tahun. Kekuasaan Jepang mulai goyah di Indonesia dengan terjadinya perang pasifik. Pada peperangan tersebut Jepang luluh lantah akibat kota Hirosima dan Nagasaki dibom oleh Tentara sekutu. Dalam suasana peperangan di Asia pasifik inilah, seorang tokoh yang bernama Soekarno berhasil memanfaatkan situasi untuk mempersiapkan kemerdekaan Indonesia.

Persiapan kemerdekaan Indonesia dimulai saat kedudukan Jepang terdesak dan mengharapkan bantuan rakyat Indoensia. Jepang saat itu sedang berjuang pada Perang Dunia II yang dipimpin oleh Perdana Menterinya yang bernama Tojo dan kemudian digantikan oleh Perdana Menteri Koiso. Perdana Menteri Koiso inilah yang menjanjikan bahwasanya Indonesia (saat itu Hindia Timur) akan merdeka dikemudian hari.
Mulai 1 Maret 1945 pemerintah pendudukan Jepang melalui Balatentara XIV, yaitu Jendral Kumakici Harada mengumumkan rencana pembentukan BPUPKI (Badan Penyelidik Usaha-Usaha Persiapan Kemerdekaan Indonesia) yang dalam Bahasa Jepangnya disebut dengan Dokuritsi Zunbi Cosakai. ${ }^{12}$

Akhirnya pada tanggal 29 April 1945 terbentuklah BPUPKI (Dokuritsu Zyumbi Tyoosakai), yang diketuai oleh KRT. Radjiman Widiodiningrat, dan beranggotakan 60 orang. BPUPKI bertugas untuk menyelidiki persoalan-persoalan politik dan kondisi lainnya untuk persiapan kemerdekaan Indonesia. ${ }^{13}$ Akan tetapi badan ini belum dapat melaksanakan tugasnya karena belum ada pelantikan para anggota secara resmi oleh pemerintah Jepang. Walaupun demikian persiapan-persiapan untuk pelaksanaan sidang Badan Penyelidik terus dilakukan. Sebagai tempat persidangan ditetapkan di Gedung Volksraad, yaitu suatu bangunan bergaya klasik Yunani-Romawi yang terletak di Pejambon. Gedung itu sebelumnya dipergunakan untuk sidang-sidang Perwakilan Rakyat di jaman Belanda. ${ }^{14}$

Permulaan sidang pertama BPUPKI yaitu pada tanggal 29 Mei 1945. Dalam sidang ini dibahas secara mendalam dasar-dasar Indonesia Merdeka. Sidang dibuka oleh Ketua Badan Penyelidik Dr. Radjiman Wediodiningrat. Yang bertindak sebagai pembicara pada tanggal 29 Mei 1945 antara lain: Muhammad Yamin, Margono, Sastrodiningrat, Wiranatakoesoemah, Soemitro, Woerjoningrat, Soerjo, Dasaad, Soesanto, Roseno, dan lain-lain. Sedangkan pada tanggal 30 Mei 1945 tercatat bertindak sebagai pembicara antara lain; Moh. Hatta, H. Agoes Salim, Samsoedin, Wongsonegoro,

12 Ridhwan Indra, Moh. 1978. Peristiwa-peristiwa di Sekitar Proklamasi 17-08-1945. Jakarta: Sinar Grafika, 1987, h. 41.

13 Retno Sasongko wati, Ensiklopedia Sejarah Nasional dan Dunia, h. 116.

${ }^{14}$ Ridhwan Indra, op.cit, h. 47. 
Abdoel Kadir, Soerachman, Soewandi, Abdoel Rahim, Soetardjo, dan Soekiman. Pada tanggal 31 Mei 1945 tercatat sebagai pembicara adalah Muh. Yamin, Sanusi, Subarjo, Soekarno, Hadikoesoemo, dan pada tanggal 1 Juni 1945 tercatat Kaswedan, Moezzakir, Soekarno, Latoeharhary dan Soekardjo. ${ }^{15}$

Sejarah mencatat bahwa yang menonjol dalam persidangan ialah perasaan kesatuan antara sesama anggota Badan Penyelidik, dan semua anggota memahami azas dan bentuk negara yang akan dibentuk dalam negara Indonesia itu nanti.. Selama masa sidang pertama terdapat tiga orang pembicara yang sangat berpengaruh yang mengemukakan pandangan-pandangan mereka tentang dasardasar negara Indonesia merdeka, yaitu terdiri dari;

Mr. Muhammad Yamin, menyampaikan pidatonya pada tanggal 29 Mei 1945 berjudul "Azas dan Dasar Negara Indonesia Merdeka". Mr. Muh.Yamin pada tanggal 29 Mei 1945 menyampaikan prasaran / usul yang disiapkan secara tertulis lebih dahulu dengan judul "Azas dan Dasar Negara Kebangsaan Republik Indonesia". yang terdiri dari lima dasar dan azas yaitu, peri kebangsaan, peri kemanusiaan, peri ketuhanan, peri kerakyatan, dan kesejahteraan rakyat/keadilan sosial. Pidato Muh. Yamin pada tanggal 29 Mei 1945 selain menyinggung tentang dasar negara, status warga negara keturunan seperti peranakan Arab, Cina, sehingga untuk hal tersebut Wakil Ketua RP. Soeroso menginterupsi pidato Yamin agar perihal warga negara tersebut dibicarakan lain waktu saja. Sehingga terjadilah sedikit perdebatan antara Muh. Yamin dengan Wakil Ketua RP. Soeroso. ${ }^{16}$

Prof. Dr. Mr. R. Soepomo. Beliau menyampaikan pidatonya pada tanggal $31 \mathrm{Mei}$ 1945, tentang masalah "Dasar-dasarnya Negara Indonesia Merdeka”. Adanya

15 Ismaun, Pengantar Ilmu Sejarah. Bandung: IKIP, 1984, h. 113.

16 Ibid, h. $87-88$ perbedaan pendapat ini dikemukakan oleh Soepomo dalam pidatonya pada tanggal 31 Mei 1945yang berbunnyi: "Memang di sini terlihat ada dua paham, paham dari anggotaanggota ahli agama yang menganjurkan supaya Indonesia didirikan sebagai negara Islam dan anjuran lain sebagaimana telah dianjurkan oleh Tuan Mohammad Hatta, ialah negara persatuan nasional yang memisahkan urusan negara dan urusan agama, dengan lain perkataan bukan negara Islam." Dalam pidatonya ini Prof. Dr. Mr. R. Soepomo juga mengemukakan tentang teori negara juridis, politis dan sosiologis, syarat-syarat berdirinya negara, bentuk negara dan bentuk pemerintahan serta hubungan antara negara dengan agama. Sebagai pembicara kedua ialah Mr. Muhammad Yamin yang menguraikan tentang Dasar Negara-Kebangsaan Indonesia atas dasar tinjauan juridis, historis, politis, sosiologis, geografis dan konstitusional yang meliputi seluruh Nusantara. Pokok-pokok pidato Prof. Dr. Mr. R. Soepomo itu membicarakan mengenai syarat mutlak dan adanya suatu negara terutama adanya faktor konstitutif, baik dari sudut hukum maupun dari sudut formal. Soepomo mengatakan adanya suatu negara harus ada suatu daerah (territority) rakyat dan harus ada pemerintah yang berdaulat (souvereign) sebagaimana syaratsyatat yang dikeluarkan oleh hukum internasional. Selain itu Soepomo mengemukakan masalah mengenai staat idea, maka untuk itu Soepomo telah memaparkan tentang teori-teori Negara dan syarat-syarat bedirinya negara serta prinsip-prinsip negara dan pemerintahan.

Ir. Soekarno, menyampaikan pidatonya pada tanggal 1 Juni 1945 tentang "Dasar Indonesia Merdeka". Dalam pidatonya Bung Karno mengatakan bahwa tentunya semua anggota BPUPKI sepakat bahwa negara yang didirikan adalah untuk semua rakyat dari ujung Aceh sampai Irian, kini Papua. "Dasar pertama, yang baik dijadikan dasar buat negara Indonesia, 
ialah dasar Kebangsaan. Kita mendirikan satu

Negara Kebangsaan Indonesia" kata Bung Karno. Bung Karno meminta maaf kepada umat Islam dan anggota BPUPKI $\mathrm{Ki}$ Bagoes Hadikoesoemo yang merupakan Ulama dari Yogyakarta sekaligus Ketua Umum PP Muhammadiyah periode 1942-1945. "Saya Saudara-saudara Islam lain, maafkanlah saya memakai perkataan kebangsaan ini! Saya pun orang Islam" tambah Bung Karno. Bung Karno telah menyampaikan 5 prinsip dasar negara yakni: 1) Kebangsaan Indonesia; 2) Internasionalisme atau perikemanusiaan; 3) Mufakat atau demokrasi; 4) Kesejahteraan sosial; 5) Bertakwa kepada Tuhan YME. ${ }^{17}$

Sementara itu golongan Islam, antara lain K.H. Wahid Hasjim, $\mathrm{Ki}$ Bagoes Hadikoesoemo, H. Agoes Salim, K.H. Abdoel Kahar Moezzakir, dalam sidang BPUPKI mengusulkan konsepsi, agar Dasar Negara Indonesia Merdeka adalah Islam. Usul dari konsepsi itupun tidak mendapat kesepakatan dari sidang. ${ }^{18}$

Berikut disajikan dalam bentuk tabel, gagasan yang mengemuka pada sidang BPUPKI dari beberapa orang tokoh nasional yang terdiri dari kelompok nasionalis dan kelompok Islam tentang dasar Indonesia merdeka. minta, Saudara Ki Bagoes Hadikoesoemo dan

\begin{tabular}{|l|l|l|l|}
\hline & Antar bangsa & Maha Esa. & \\
\hline
\end{tabular}

Pada bagan di atas dapat dilihat gagasan tentang dasar Negara yang dikemukakan oleh para tokoh bangsa. Gagasan yang terdapat pada kolom satu sampai tiga, terlihat begitu identik, yakni mengusung konsep kebangsaan pada nomor awalnya. Konsep gagasan seperti ini muncul dari tokohtokoh nasionalis. Sepertinya para tokoh nasionalis lebih mementingkan rasa persatuan dan semangat kebangsaan dibanding landasan religiusitas. Akan tetapi pada kolom nomor empat terlihat bahwa bagi tokoh Islam, agama adalah di atas segala-galanya, sehingga mereka mengusung konsep dasar Indonesia merdeka adalah hukum Islam yang bersumber pada Alquran dan hadis.

Bagan di atas menggambarkan bahwa sidang BPUPKI dalam merumuskan dasar Negara Indonesia merdeka berjalan cukup alot, karena di dalam kepengurusan BPUPKI terdapat 2 kelompok yang mengusung 2 gagasan berbeda. Gagasan yang lahir tersebut berasal dari anggota BPUPKI yang berjumlah 62 orang, yang secara rinci terdiri dari 15 orang golongan Islam menginginkan Indonesia berdasarkan syariat Islam dan 47 orang nasionalis menginginkan Indonesia berasaskan kebangsaan.

Berhubung belum ditemukannya

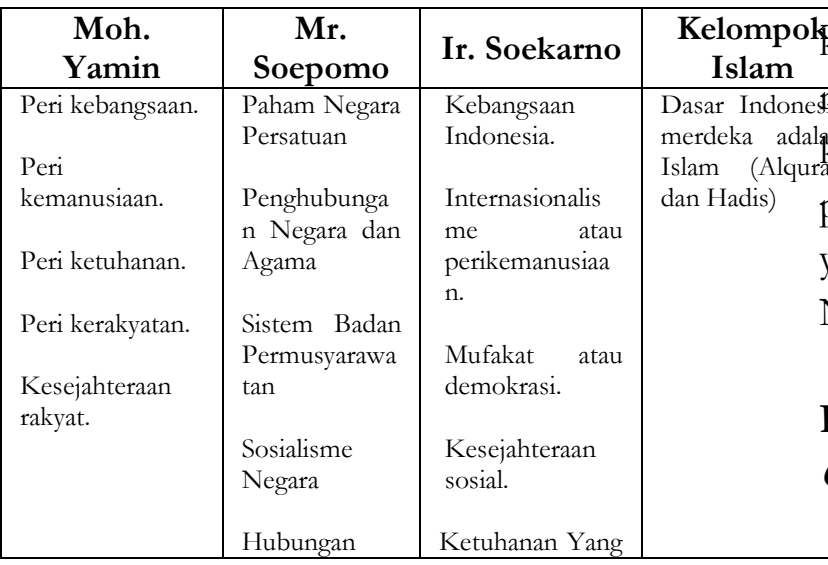

17 Ridhwan Indra, Moh. 1978. Peristiwa-peristiwa di Sekitar Proklamasi 17-08-1945. Jakarta: Sinar Grafika, h. 36 .

18 Ibid, h. 37.

\section{PIAGAM CHARTER)}

Piagam Jakarta yang dalam bahasa Inggrisnya disebut dengan Jakarta Charter, adalah sebuah dokumen yang disusun oleh panitia sembilan BPUPKI yang merupakan dokumen historis berupa sebuah kompromi 
antara pihak Agama Islam dengan Pihak Kebangsaan untuk menghilangkan perbedaan antara agama dan negara pada tanggal 22 juni 1945. Piagam ini merupakan awal dari terbentuknya pembukaan Undang-Undang Dasar tahun 1945 (UUD 1945).

Piagam Jakarta lahir melalui sejarah yang cukup panjang dan sangat mengesankan bagi umat Islam. Ia lahir berkat kegigihan umat Islam untuk meujudkan cita-cita religius dalam kehidpan berbangsa dan bernegara. Berkat kegigihan tersebut kelompok nasionalis tidak dapat berbuat banyak dalam mengusung asas kebangsaan sebagai dasar utama Negara Indonesia merdeka. Akibat adanya konsep rumusan yang berbeda antara kelompok nasionalis dan kelompok Islam, maka dipandang perlu untuk membentuk panitia kecil yang bertugas membahas usul-usul baik lisan maupun tertulis yang diajukan oleh para anggota tokoh nasional yang tergabung di dalam BPUPKI. Panitia kecil yang dibentuk oleh BPUPKI pada 1 Juni 1945 dikenal dengan sebutan Panitia Sembilan. Panitia Sembilan ini adalah panitia yang beranggotakan 9 orang yang bertugas untuk merumuskan dasar negara Indonesia yang tercantum dalam UUD 1945. Adapun anggota Panitia Sembilan adalah sebagai berikut: ${ }^{19}$

1. Ir. Soekarno (ketua)

2. Drs. Moh. Hatta (wakil ketua)

3. Mr. Achmad Soebardjo (anggota)

4. Mr. Muhammad Yamin (anggota)

5. KH. Wachid Hasyim (anggota)

6. Abdul Kahar Muzakir (anggota)

7. Abikoesno Tjokrosoejoso (anggota)

8. H. Agus Salim (anggota)

9. Mr. A.A. Maramis (anggota)

Sembilan orang tersebut berasal dari 2 perwakilan; 5 orang mewakili golongan nasionalis dan 4 orang mewakili golongan Islam. Empat orang yang mewakili golongan Islam, yaitu Abikoesno Tjokrosoejoso (Partai Sarekat Islam Indonesia), Abdul Kahar

\footnotetext{
${ }^{19}$ Ridhwan Indra, Moh. 1978. Op.cit, h. 50.
}

Muzakkir (Muhammadiyah), Agus Salim (mantan tokoh Partai Sarekat Islam Indonesia dan pendiri Pergerakan Penyadar), dan Abdul Wahid Hasyim (Nahdlatul Ulama). ${ }^{20}$

Tugas Panitia Sembilan adalah menyusun sebuah naskah rancangan pembukaan hukum dasar yang kemudian oleh Mr.Muhammad Yamin diberi nama "Piagam Jakarta". Piagam Jakarta memuat rumusan dasar negara sebagai hasil yang pertama kali disepakati oleh sidang. Rumusan dasar negara yang termuat dalam Piagam Jakarta adalah;

1. Ketuhanan dengan kewajiban menjalankan syariat Islam bagi pemelukpemeluknya.

2. Kemanusiaan yang adil dan beradab.

3. Persatuan Indonesia.

4. Kerakyatan yang dipimpin oleh hikmat kebijaksanaan dalam permusyawaratan/perwakilan.

5. Kadilan Sosial bagi seluruh rakyat Indonesia.

Kemudian pada tanggal 1 Juli 1945, Panitia Perancang UUD menyetujui bahwa isi pembukaan UUD akan diambil dari isi Piagam Jakarta.

Dalam masa sidang kedua BPUPKI pada 10 Juli 1945, Sukarno menyampaikan rumusan Piagam Jakarta. Soekarno pada saat itu bersungguh-sungguh meyakinkan anggota sidang untuk menerima Piagam Jakarta sebagai rumusan terbaik pembukaan UUD 1945. Para founding fathers sepakat mempertahankan kalimat: "Ketuhanan Dengan Kewajiban Menjalankan Syariat Islam bagi PemelukPemeluknya." Sidang BPUPKI tanggal 10 Juli sampai 17 Juli 1945 merupakan Babak Perumusan yang berhasil merumuskan "Rancangan Dasar Negara Dan Hukum Dasar", yakni Piagam Jakarta sebagai Mukadimah, Hukum Dasar, Naskah Pernyataan Indonesia Merdeka. Pada tanggal

20 http://wawasansejarah.com/piagam-jakartal, diakses tanggal 29 Mei 2018, pukul 15.43 WIB 
17 Juli 1945 semua rancangan Hukum Dasar Negara Indonesia Merdeka selesai. ${ }^{21}$

Yang perlu disoroti pada masa sidang kedua BPUPKI ini adalah lahirnya Piagam Jakarta yang telah melalui proses yang bersejarah di dalam kehidupan kenegaraan Indonesia. Hal ini dimulai dengan adanya inisiatif dari sekian banyak inisiatif pemimpinpemimpin Indonesia itu dari golongan alim ulama Islam telah menyampaikan surat inisiatif sebagai usul saran tentang bentuk dan ketentuan-ketentuan yang akan digunakan bagi Indonesia merdeka nanti. Pada saat itu suratsurat dari alim ulama dan pemimpin-pemimpin Islam yang diterima di meja Djawa Hokokai berjumlah 52 ribu surat yang terdaftar. Sehingga pada waktu panitia Dokuritsu Zyunbi membawa tentang perbuatan persiapan Undag-Undang Dasar terlebih dahulu disusunnya satu preambul (mukadimah) dan preambul inilah yang pertama kali berwujud piagam Jakarta. Maka bagaimanapun juga Piagam Jakarta itu banyak mendapat ilham daripada hikmah 52 ribu surat-surat dari para alim ulama dan pemimpin-pemimpin Islam itu. $^{22}$

Yang dimuat dalam piagam tersebut adalah buah kompromi antara golongan Islam dan golongan kebangsaan. Pasal 28 Bab X tentang agama yaitu; ${ }^{23}$

1. Negara berdasarkan ketuhanan, dengan kewajiban menjalankan syariat Islam bagi pemeluk-pemeluknya.

2. Negara menjamin kemerdekaan tiap-tiap penduduk untuk memeluk agama dan untuk beribadat menurut agamanya masingmasing

Itulah hasil dari diskusi panjang mengenai batang tubuh Undang-Undang Dasar. Perdebatan selanjutnya beralih pada

${ }^{21}$ Ismaun, Op. cit, h. 114.

22 Endang Saifuddin Anshari, Piagam Jakarta 22 Juni 1945: Sebuah Konsensus Nasional Tentang Dasar Negara Republik Indonesia (1945-1959), Jakarta: Gema Insani Press, 1997, h. 22.

${ }^{23}$ Endang Saifuddin Anshari, Ibid, h 24. apakah presiden harus seorang muslim ataukah tidak. Bahwa di dalam UndangUndang Dasar dituliskan bahwa Presiden Repubik Indonesia haruslah orang Indonesia asli yang beragama Islam. Rakyat Indonesia terdiri dari pada 90\% atau 95\% orang-orang yang beragaa Islam, bagaimanapun, tidak boleh tidak nanti yang menjadi Presiden Indonesia tentulah yang beragama Islam. Piagam Jakarta, yang dirancang dan dirumuskan serta dipertahankan oleh Panitia Sembilan merupakan hasil akhir perjuangan yang panjang untuk kemerdekaan dan dalam waktu yang sama merupakan titik tolak pembangunan dan perkembangan masa mendatang. Maka dengan ilham Piagam Jakarta pula tersusunlah Undang-Undang Dasar 1945 yang lazim disebut sebagai Undang-Undang Dasar Proklamasi.

Sabtu pagi, 18 Agustus 1945, sebelum sidang Panitia Persiapan Kemerdekaan Indonesia (PPKI) dimulai, Hatta dan Sukarno menggelar rapat nonformal bersama sejumlah tokoh Islam, di antaranya $\mathrm{Ki}$ Bagus Hadikusumo, Wahid Hasyim, dan Teuku Mohammad Hasan. Rapat membahas permintaan perwakilan Indonesia timur untuk menghapus kalimat yang mewajibkan syariat Islam bagi pemeluknya dalam Piagam Jakarta. Jika permintaan itu tidak dipenuhi, perwakilan Indonesia timur mengacam akan memisahkan diri dari Indonesia. Bagi sejumlah tokoh Islam, permintaan itu sulit diterima. Sebab, bagi sebagian mereka, menerapkan syariat Islam merupakan salah satu alasan mengapa perjuangan memerdekakan Indonesia dilakukan. Namun para tokoh Islam juga sadar membiarkan Indonesia timur berpisah akan melemahkan posisi diplomasi Indonesia di mata dunia. Sehingga Belanda bisa dengan mudah kembali menjajah.

Dan pada sidang PPKI tanggal 18 Agustus 1945, Hatta mengusulkan 4 perubahan di dalam UUD 45: 
1) Kata "Mukaddimah" diganti dengan kata "Pembukaan"

2) Dalam Preambul (Piagam Jakarta), anak kalimat "berdasarkan kepada ketuhanan, dengan kewajiban menjalankan syariat Islam bagi pemeluk-pemelukny" diubah menjadi "berdasar atas Ketuhanan Yang Maha Ea"

3) Pasal 6 ayat 1 "presiden ialah orang Indonesia asli dan beragama Islam" katakata "beragama Islam" di coret.

4) Sejalan dengan perubahan yang kedua di atas, maka pasal 29 ayat 1 menjadi "Negara berdasarkan atas Ketuhanan Yang Maha Esa" sebagai pengganti "Negara berdasarkan atas keuhanan, dengan kewajiban menjalankan syariat Islam bagi pemeluk-pemeluknya" 24

Setelah membacakan perubahanperubahan tersebut, Hatta menyatakan keyakinannya "inilah perubahan yang maha penting menyatukan segala bangsa". Piagam Jakarta yang diperdapat dengan susah payah, dengan memeras otak dan tenaga berhari-hari oleh tokoh-tokoh terkemuka dari bangsa kita, kemudian di dalam rapat "Panitia Persiapan Kemerdekaan" pada tanggal 18 Agustus 1945 di dalam beberapa menit saja dapat diubah.

"Kejadian yang mencolok mata itu, dirasakan oleh umat Islam sebagai suatu permainan sulap yang masih diliputi oleh kabut rahasia sebagai permainan politik pat gulipat terhadap golongannya, akan tetapi mereka (umat Islam) diam, tidak mengadakan tantangan dan perlawanan karena jiwa toleransi mereka," ujar tokoh Masyumi, M. Isa Anshari dalam sidang Konstituante 1957, seperti dikutip dalam Piagam Jakarta 22 Juni 1945 (1981). Kekecewaan Isa tertuju kepada Sukarno. Ia mempertanyakan peran Sukarno yang terkesan inkonsisten. Sebab, menurut Isa, Sukarno lah yang semula gigih mempertahankan Piagam Jakarta di sidang BPUPKI, tetapi Sukarno jugalah yang

\footnotetext{
${ }^{24}$ Endang Saifuddin, op.cit, h. 38
}

dianggapnya berkontribusi mengganti isi Piagam Jakarta. ${ }^{25}$

Sehubungan dengan ini, Letnan Jenderal Soedirman menulis, pada waktu itu situasi dan kondisi tanah air masih di dalam mara bahaya, di mana tentara sekutu sudah mengelilingi bangsa Indonesia dengan tujuan akan mengembalikan kolonialisme Belanda/Nica untuk menjajah kembali. Hal ini mengancam kedaulatan bangsa dan Negara. Itulah sebabnya kelompok Nasionalis Islam menyampingkan dulu prinsip-prinsip tentang filsafat Negara dan konstitusi Islam.

Dari perjalanan panjang dan usaha maksimal tokoh-tokoh Islam baik yang berada di daerah maupun yang berada di pusat, terlihat bahwa hukum Islam mampu mewarnai dasar negara dan konstitusi Indonesia. Hal ini dapat terlihat pada rumusan dasar negara Indonesia merdeka, pada sila pertama dicantuman kata-kata, "Negara berdasarkan kepada ketuhanan yang Maha Esa dengan kewajiban menjalankan syari'at Islam bagi para pemeluknya". Kalimat ini selanjutnya dituangkan ke dalam pembukaan dan batang tubuh UUD negara. Pada masa-masa sidang BPUPKI terlihat bahwa umat Islam terus mengawal aktifitas badan ini. Hal tersebut dapat dibuktikan dengan masuknya 52 ribu lebih surat dari umat Islam ke BPUPKI, yang berisi usulan tentang dasar negara Indonesia merdeka. Selain pengawalan ketat dari umat Islam di selurh penjuru Nusantara, tokohtokoh Islam yang duduk dalam keanggotaan BPUPKI juga selalu gigih untuk memasukkan konsep Hukum Islam ke dalam dasar Negara.

Kegigihan umat Islam untuk memperjuangkan eksistensi hukum Islam dalam kehidupan berbangsa dan bernegara terlihat tidak hanya untuk persiapan kemerdekaan saja tetapi jauh sejak ratusan tahun sebelumnya. Hal itu berlanjut sampai

25 https://tirto.id/sukarno-dalam-polemikpiagam-jakarta-cq7m, akses terakhir tanggal 29 Mei 2018, pukul 16. 37. 
saat ini. Jika dilihat secara historis, dapat disimpulkan bahwa jiwa-jiwa perjuangan umat Islam untuk kehidupan politik sudah tertanam secara turun-temurun, bahkan perjuangan itu masih tetap berlangsung sampai pada tahun kemarin, saat ini, dan besar kemungkinan akan berlanjut terus sampai masa yang akan datang.

Pada tahun kemarin telah menjadi catatan panjang sejarah yang terukir sangat dalam dalam pentas perpolitikan Indonesia. Wakil umat Islam dari seluruh penjuru nusantara hanya dengan digerakkan oleh kalimat tauhid telah melakukan aksi besarbesaran di Jakarta, tepatnya di area Monumen Nasional dan sekitarnya. Aksi tersebut dilatarbelakangi ketidakinginan umat dipimpin oleh pemimpin kafir. Semangat jihad yang membara telah membuahkan hasil yang menggembirakan, yakni dengan lengsernya Basuki Cahaya Purnama yang lebih dikenal dengan Ahok dari jabatan Gubernur DKI dan vonis pidana yang dijatuhkan untuk dia. Fenomena politik tersebut tidak terlepas dari peran besar umat Islam yang melakukan gerakan di ibu kota negara terkait dengan percaturan politik bangsa.

Dari aksi-aksi sejarah yang muncul sejak dahulu, terlihat bahwa setiap gerakan umat Islam yang terpusat di Ibu kota negara akhirnya akan membuahkan hasil yang menggembirakan bagi umat Islam khususnya dan bagi bangsa Indonesia umumnya. Dan sepanjang sejarah telah tercatat bahwa ruh siyasah syar'iyah (politik hukum Islam) telah menginfiltrasi ke dalam kehidupan berbangsa dan bernegara sekalipun secara eksplisit tidak dapat terlihat secara nyata.

\section{KESIMPULAN}

Indonesia adalah sebuah Negara yang telah menemukan kedaulatan sejak 17 Agustus1945. Sebelum merdeka Indonesia dijajah oleh beberapa bangsa dalam decade yang cukup panjang. Penjajahan Belanda terhadap Indonesia berlangsung selam 3,5 abad dan kemudian dilanjutkan oleh Jepang selama 3,5 tahun. Dampak terjadinya perang di Asia Pasifik telah membawa berkah terhadap Indonesia. Dalam suasana yang cukup tegang Indonesia berusaha untuk mempersiapkan kemerdekaan.

Persiapan kemerdekaan secara formal dimulai dengan pembentukan BPUPKI. Setelah satu bulan terbentuknya, BPUPKI mulai mengadakan sidang untuk mempersiapkan kemerdekaan Indonesia. Sidang tersebut dilakukan dalam 2 periode, periode pertama membahas dasar Negara Indonesia merdeka dan pada sidang kedua disepakati dasar Negara dan rumusan hukum dasar Indonesia merdeka.

Perumusan dasar Negara pada sidang BPUPKI berjalan cukup alot karena ada sejumlah usul dari berbagai kalangan. Secara garis besar anggota BPUPKI terbagi ke dalam 2 kelompok yaitu kelompok nasionalis dan kelompok Islam. Kelompok Islam menginginkan dasar Negara Indonesia merdeka adalah ajaran Islam, sedangkan kelompok nasionalis menginginkan dasar Indonesia merdeka adalah kebangsaan. Perujudan keinginan dari kelompok Islam tersebut tertuang pada rumusan Piagam Jakarta yang berbunyi Negara berdasarkan ketuhanan yang maha Esa dengan kewajiban menjalankan Syari'at Islam bagi pemeluknya, dan di dalam rancangan hukum dasar Negara Indonesia juga tercantum hal seperti itu.

Pada awalnya rumusan Piagam Jakarta tersebut telah disepakati oleh para tokoh bangsa yang tergabung dalam BPUPKI. Hal ini mendatangkan kegembiraan yang sangat berarti bagi umat Islam Indonesia umumnya dan tokoh bangsa khususnya. Islam telah mampu mewarnai kehidupan bernegara melalui rumusan tersebut. Akan tetapi pada tangal 18 Agustus kesepakatan tersebut berubah, sehingga kata-kata kewajiban menjalan syari'at Islam bagi para pengikutnya raib dari rumusan. Setelah ditelusuri kenyataan 
itu tejadi karena tuntutan dari tokoh-tokoh Indonesia Timur yang keberatan dengan dicantumkannya kata-kata tersebut. Tokoh Islam mengabulkan tuntutan tersebut demi keutuhan bangsa dan Negara, apalagi saat itu Indonesia masih berada dalam kondisi labil, karena NICA akan kembali ke Indonesia.

Tegaknya Negara Indonesia tidak terlepas dari perjuangan umat Islam seluruh penjuru Nusantara. Perjuangan umat Islam tersebut tidak hanya pada masa lampau tapi terus berlanjut sampai hari ini dan masa yang akan datang. Perjuangan tidak akan pernah berhenti sampai kehidupan kenegaraan benarbenar berdasarkan kepada siayasah syar'iyah (politk hukum Islam). Sekalipun secara formal dan ekspilit tidak pernah dicantumkan istilah siyasah syari'iyah, tetapi umat Islam akan terus memperjuangakan eksistensinya tetap terpelihara dalam kehidupan berbangsa dan bernegara. 


\section{DAFTAR KEPUSTAKAAN}

Abdurrahman taj, Al-siyasah al-Syar'iyah wa al-Fiqh al-Islami, Mesir : Mathba'ah Dar al-Ta'lif, 1993.

Anshari, Endang Saifuddin, Piagam Jakarta 22 Juni 1945 : Sebuah Konsensus Nasional Tentang Dasar Negara Republik. Indonesia (1945-1959), Jakarta : Gema Insani Press, 1997.

Azhary, Muhammad Tahir, Negara Hukum Suatu Studi Tentang Prinsip-prinsipnya dilihat dari Segi Hukum Islam, Implementasinya pada Periode Negara Madinah dan Masa Kini, Jakarta: Bulan Bintang, 1992.

Khallaf, Abdul Wahab, Siyasah Syar iyyah Aw Nizam al-Daulah Islamiyah Fi Syun al-Dusturiyah wa alKharijiah wa al-Maliyab; Kaherah, Dar al-Ansar, 1982.

Iqbal, Muhammad, Fiqh Siyasah ,Kontekstualisasi Doktrin Politik Islam Jakarta : Penerbit Gaya Media Pratama, 2001.

Ismaun, Pengantar Ilmu Sejarah. Bandung: IKIP, 1984.

Mahfud, MD., Moh.., Politik Hukum di Indonesia, Jakarta : LP3ES, 1998.

Pulungan, Suyuthy, Figh Siyasah, Ajaran, Sejarah dan Pemikiran, Jakarta : Rajawali, 1994.

Ridhwan Indra, Moh. Peristiwa-peristiwa di Sekitar Proklamasi 17-08-1945. Jakarta: Sinar Grafika, 1987.

Sunny, Isma’il, Tradisi dan Inovasi Keislaman di IndonesIa dalam Bidang Hukum Islam, dikutip dari Bunga Rampai Peradilan Islam di Indonesia, Jilid I, Bandung: Ulul Albab Press, 1997.

Taqiyuddin, An-Nabhani, Muqaddimah al-Dustur, Juz I , Beirut : Darul Ummah, 2003.

Wati, Retno Sasongko, Ensiklopedia Sejarah Nasional dan Dunia, tt : tp. t.th

http://ditakharismasafitri.blogspot.com/2017/04/kedatangan-bangsa-eropa-dan-awal-mula.html, akses terakhir hari Senin tanggal 28 Mei 2018, pukul 14.05 WIB.

http://wawasansejarah.com/piagam-jakartal, diakses tanggal 29 Mei 2018, pukul 15.43 WIB

https://tirto.id/sukarno-dalam-polemik-piagam-jakarta-cq7m, akses terakhir tanggal 29 Mei 2018, pukul 16. 37. 
balaman ini tidak disengaja kosong 